\title{
Trade Liberalization and its Environmental Impact in India: An Empirical Analysis
}

\author{
Ranjan Aneja ${ }^{1}$ and Ummed Singh ${ }^{2}$ \\ ${ }^{1}$ Assistant Professor, Department of Economics, Central University of Haryana, Mahendergarh, Haryana, India \\ ${ }^{2}$ Assistant Professor, Department of Economics, University of Rajasthan, Jaipur, Rajasthan, India \\ E-Mail: drummedsinghuniraj@gmail.com
}

\begin{abstract}
The debate on the impact of trade on environment is pertinent considering the increasing volume of trade among world nations and the changes in environmental quality. In India, this increase was higher because of the gradual lifting of the quantitative restrictions and reduction in tariffs after trade liberalization in 1991. The pollution haven effect occurs when trade liberalization, coupled with lax environmental regulations results in increasing economic activities in pollution intensive industries. Using industry level data for the period 1998-2008, for fifty eight manufacturing industries in India, this paper looks at output and export trends and attempts to examine, whether trade liberalization is associated with a shift in production and exportation towards pollution intensive goods industries (pollution haven effect). Manufacturing output has been significantly higher from the water pollution intensive sectors compared to the air and toxic pollution intensive sectors. This evidence provides some support for concerns that there is significant contribution in production of manufacturing industries from dirty industries. The results of the study suggest that while trade liberalization measures have been pursued to promote economic growth in India but they have led to some potentially adverse environmental consequences.
\end{abstract}

Keywords: Trade liberalization, Pollution haven effect, Quantitative restrictions, Central pollution control board, NAFTA

\section{INTRODUCTION}

For the past decade and a half, environmentalists and the trade policy community have been engaged in a heated debate over the environmental consequences of liberalized trade. This debate has been intensified by the creation of World Trade Organization (WTO) and subsequent commencement round of NAFTA, Uruguay round and Doha round on trade negotiations. Since economic reforms, the Indian economy has witnessed a high economic growth along with the increase in its share in global trade. After trade liberalization, India is growing with an annual average rate of 8 percent which was only 3.1 percent during the prereform period. Both exports and imports have increased substantially after liberalization. The annual average growth rate of exports increased from 7.6 per cent during 1981-91 to 10 per cent during 1992-2000 and that of imports increased from 8.5 to 13.4 per cent for the same period. India's share in global exports increased from 0.52 per cent in 1990 to 0.67 per cent in 2000. This increase was higher because of the gradual lifting of the quantitative restrictions and reduction in tariffs. Concomitantly there has been greater integration of the global economy on account of liberalization of international trade and lowering of barriers to cross border investment flows.

In 1990-91, industry sector contributed 26 percent of India's gross domestic product (GDP), employing 15 percent of the workforce and using 39 percent of the economy's net renewable capital stock. In the 1980s, industry was the economy's leading sector, growing annually at around 6 percent, while the domestic output grew annually at around 5.5 per cent and exports at 8.5 percent (in current dollar terms). By the two-digit industry groups, beverages (National Industrial Classification [NIC 22]) recorded the fastest growth of 12 percent per year. Table 3 represents the trend growth rates for two digit industry groups for total manufacturing GDP using the national account statistics. Electrical machinery (NIC 31 and 32) grew faster in the 1980 s at 12.7 percent per year, while transport equipment fared better after the reforms of 1991(see Table 3).

The composition of India's export and imports has also altered significantly during the study period. While, the share of manufactured goods and primary products in total exports declined from 73.6 percent to 64.6 percent and from 23.1 percent to 14.8 percent respectively. The OPEC and Asian developing countries became major market for India's export, while EU, Eastern Europe and OECD countries have become less important for India's export as compared to 1991-92. The degree of concentration of trading partners, as measured by Herfindhal Index, increased from 0.16 in 1991 to 0.19 in 2010 which indicates increased concentration or reduced diversification. On account of linkage between trade and the environment through scale, composition and technique effects, this shift in India's trade partners could have important implication for the environmental quality and use of natural resources.

Trade liberalization is assumed to encourage the economic growth in the developing countries. It opens up the economy for foreign market; investment, capital flows, and reduces the trade barriers. Although, it may promote the growth but at the same time it may increase the pollution level either due to relocation of polluting industries from countries with strict environmental policy or because of increased production level in dirty industries. There is a common belief among economists and policy makers that 
more trade openness has increased the pollution level, particularly in developing countries. Liberalized trade regimes and market-driven exchange rates, by increasing the incentive for export led to a greater exploitation of natural resources. In developed countries the environmental regulations are more stringent and therefore, there is a tendency of displacement of dirty industries from developed to developing countries. In developed countries the cost of complying with environmental regulations is comparatively high than the developing countries, hence, these countries have comparative advantage in pollution intensive production. Thus "pollution havens" arise. Therefore, in this context it is important to examine whether such policies are in fact in conflict with the environment.

In India, trade liberalization program led to economic growth and development but this development took place at the cost of environmental damages, either in the form of air and water pollution or depletion of natural resources and now recent emergence of global environmental issues such as climate change, global warming, ozone depletion and acid rain. Increasing free trade in countries with weak environmental norms and regulations has raised concerns about the adverse environmental consequences of trade liberalization policies. There is a concern that trade liberalization could potentially encourage the use of India as a production base for more pollution intensive production (Jha and Rabindran, 2004).

\section{TRADE REFORMS IN INDIA}

In the Indian economy, trade reforms were introduced in June 1991 through trade liberalization. The basic objective of new trade policy was to remove the trade restrictions and licensing rule. Prior to the 1991 reforms, the Indian government controlled trade through various forms of restrictions such as, import licensing requirements and tariffs. Trade reforms broadly covered four areas - reduction of tariff rates, easing exchange control regulations, liberalizing imports licensing requirements and the rationalization of export subsidies. Import licensing was an important mode of protection used by the Indian government before 1991. Prior to 1991, all imports unless specifically exempted, required a license or a customs clearance permit. All imports classified under four main licensing types, namely, restricted items, banned items, limited permissible, or open general license (OGL). In practice, although goods classified to open general license were exempted from licensing requirements, many OGL imports required government approval or were subject to "actual user" conditions. Following trade liberalization of 1991, the different forms of import licenses were replaced by consolidated 'Negative List of Imports'. Goods not on the negative list were freely importable. In the area of industrial policy, before 1991, compulsory industrial licensing was required to set up any new plant, either for capacity expansion or as a new business enterprise. The new industrial policy of 1991 abolished industrial licensing in all, except nine sectors of strategic concern such as defense, aircrafts and warships, railways and atomic energy generation.

The rupee was adjusted downwards by about 22 percent in July 1991 and is now determined by market forces. Two of the important points of industrial policy in the pre-reforms period had been the MRTP Act 1969 (which subjected investment by large industrial houses to several restrictive provisions) and the FERA Act 1973 (which imposed strict limits on foreign exchange transactions on the current as well as capital account). Both now stand replaced by much more liberal versions the competition Act 2002 and the FEMA 1999. Further, several liberalization measures for attracting foreign direct investment (FDI) were introduced in the wake of the reforms in 1991, while foreign portfolio investment (FPI) was also selectively liberalized from 199596 onwards. LERMS (Liberalized Exchanged Rate Management System) introduced in March 1992. Under LERMS, virtually all capital goods and raw material are made freely importable subject to tariff protection as long as foreign exchange to pay for imports is obtained through the market. The maximum tariff was lowered from $250 \%$ in 1991 to $65 \%$ in $1994,50 \%$ in 1995 and $40 \%$ in $1996-97$.

India signed the MIGA (Multilateral Investment Guarantee Agency) protocol for the protection of foreign investments in April, 1992. The duty on capital goods was reduced from $25 \%$ to $20 \%$. A number of export subsidies such as, cash compensatory supports for exports have been abolished. A number of measures to strengthen the development of Export Houses and Trading Houses as an instrument of promoting exports were announced. The Export Processing Zones (EPZ) scheme and the 100\% Export Oriented Unit (EOU) scheme were liberalized to include agriculture, horticulture, aquaculture, poultry, and animal husbandry.

\section{ENVIRONMENTAL POLICY IN INDIA}

The introduction of the economic reform in 1991 witnessed a rapid growth in India. It resulted in rapid resources depletion and ecological degradation. On one hand, higher targets of economic growth increases pressure on already overburdened natural resources and on the other hand, improved economic conditions of people induce changes in their consumption patterns and life style which often lead to increased environmental stress. In the pre-reform period, environmental issues were considered external to the economy. But soon it was realized that this approach towards environmental might result in an irreversible damage to our ecosystems that would be beyond our control. Probably, this motivated the government of India to prepare national environmental action plan in the postreform period, aimed at integrating the environmental considerations into the development strategies. Since the beginning of the environmental movement in the early 1970 s, India has played a proactive role in framing the relevant policies such as passage and codification of various acts to safeguard the environment. This produced exhaustive and stringent environment legislation in the country. However, implementation and enforcement of 
various laws and policies have not been very effective, as a result of which an unsustainable use of natural and environmental resources is continued in the country. There are several reasons for the limited success of environmental policies, such as institutional failure and public unawareness. India was the first country to amend its constitution and empower the state to protect and improve the environment for safeguarding public health, forests and wildlife. India participated at the United Nations conference on human environment held in Stockholm in June 1972 and decided to take appropriate steps for the protection and improvement of environment and the prevention of hazards to human life and health and suggested urgent remedial measures for a sustainable development. The $42^{\text {nd }}$ amendment to the constitution was adopted in 1976 and came into effect in 1977, focused on these issues.

India has an elaborate legal framework of national laws for control of environmental pollution. The overarching legislation in this context is The Environment (Protection) Act, 1986, which was a response to the Bhopal gas tragedy of 1984. It is the umbrella act in India that deals with the overall management of ecosystems in the country. In addition, some of the important national policies and the Acts are Indian Forest Act, 1927; Wildlife (Protection) Act, 1972; Water (Prevention and Control of Pollution) Act, 1974; Forest Conservation Act, 1980; Air (Prevention and Control of Pollution) Act, 1981; National Forest Policy, 1988; Public Liability Insurance Act, 1991; National Conservation Strategy and Policy Statement on Environment and Development, 1992; Policy Statement on Abatement of Pollution, 1992; National Environmental Tribunal Act, 1995; National Environment Appellate Authority Act, 1997; National Agriculture Policy, 2000; National Water Policy, 2002; National Environmental Policy(NEP), 2006; National Green Tribunal (NGT) Act, 2010.

The Ministry of Environment and Forests was created in 1985 and since then it has been the nodal agency for all issues related to environment and forests. It is responsible for all environmental functions such as monitoring, assessments, surveys, enforcement, co-ordination and promotional work. It has empowered the central pollution control board (CPCB) at Delhi and several state pollution control board (SPCB) in various states as well as pollution control committees (PCCs) in the union territories to implement and enforce environmental regulations. For the purpose of our analysis, the important point to note is that CPCB has identified 2301 medium and large scale polluting industrial units under 17 highly polluting categories. The requisite pollution control devices are provided in 1927 units, while 235 have been closed and 139 are still defaulting.

\section{REVIEW OF LITERATURE}

Antweiler et al. (2001) examined that how openness to trading opportunities affects pollution concentrations. They started with a theoretical specification. In empirical section they separately estimate composition, scale and technique effects of trade on the environment, using regression analysis. They found negative environmental consequences of the scale effects and positive environmental consequences of the technique effects. They estimate that a 1 percent increase in the scale of economic activity raises pollution concentrations by 0.25 to 0.5 percent, but the accompanying increase in income drives concentrations down by 1.25 to 1.5 percent via a technique effect.

Azhar et al. (2006) applied Johanson-Juselius Cointegration technique and error correction model using the time series data for Pakistan economy over the period of 1972-2001. The paper finds the existence of a cointegrating vector, indicating a valid long run relationship among the trade liberalization and environmental indicators. In long run, trade liberalization causes to increase air and water pollution. The results support that trade liberalization have a negative impact on environmental indicators.

Beghin and Potier (1997) took five specific manufacturing sectors: chemicals, electronics, metals, automobiles and textiles and clothing which were at different development levels. They concluded that trade liberalization will not induce wholesale specialization in dirty manufacturing industries in the developing world. To the contrary, several situations are likely to arise as more efficient resource allocation benefits the environment in several industrial sectors.

Grossman and Krueger (1993) supply evidence with a cross country study that emissions of both sulphur dioxide $\left(\mathrm{SO}_{2}\right)$ and dark matter (smoke) grow with income until a certain threshold, above which emissions begin to diminish. Thus, emissions plotted with respect to income follow an invertedU shape (EKC).

Jena et al. (2006) examine the validity of pollution heaven hypothesis in the Indian context after post liberalization period. They used a polled cross-section model using a sample of 17 states to find out that who is more responsible for influencing and damaging the environmental qualityFDI or regional development during the study period. They found not strong evidence for support PHH in India. They concluded that regional economic growth and development is more responsible for the accumulation and concentration of air pollutants than foreign investment inflow. But authors alert that pollution heaven arguments cannot be taken lightly.

Jha and Rabindran (2004) found that exports and FDI grew in the more polluting sectors relative to the less polluting sectors in the post-liberalization period. They examined the correlation between the measures obtained from the CPCB and the IPPS for 1999. They find a high degree of correlation ( 0.87 ) between the CPCB pollution-intensity measures and IPPS pollution-intensity measure for water pollution-intensity and a moderate degree of correlation (0.46) between the air pollution-intensity measures 
generated from the two sources. This evidence suggests correspondence between the IPPS estimates and the actual pollution load of Indian industries.

Kukla (2008) investigated the impact of economic growth and international trade on the level of air pollution. The author used structural equation model and measurement model with two factors which show changes in the structure of the economic activity and air pollution intensity. Author further assumed that both factors are affected by per capita income, international trade intensity and the political rights and civil liberties index. Author concluded that the impact of economic growth on environmental quality varies between the developing and developed countries. In the developing countries, this impact occurs through higher per capita income and higher international trade intensity, which lead to changes in the structure of the economic activity. But in developed countries, this impact occurs direct which is corresponds to the sum of the scale effect and income effect. This study also confirms that environmental quality improves with higher level of political rights and civil liberties.

Mukhopadhyay (2006) used input-output techniques for evaluating the impact on the environment of Thailand's trade with OECD countries, focusing on the two conflicting hypothesis (Pollution Haven Hypothesis and Factor endowment Hypothesis) considering three pollutants, Carbon dioxide, Sulfur dioxide and Nitrogen oxide $\left(\mathrm{CO}_{2}\right.$, $\mathrm{SO}_{2}$ and $\mathrm{NO}_{2}$ ). Author's result support pollution Heaven Hypothesis implying that export related pollution is much greater than the import related pollution for 2000. On the other hand her findings did not support and challenge the factor endowment hypothesis thus, confirming that the Thailand's exports required more capital than did its import in 2000. Author also investigated the role of environment regulations, factor endowments, trade policies, environment energy policies and implications of FDI on the Environment. This study has important implications for other developing countries, which are also following a similar export-driven growth path induced by FDI. This study suggests the implementation of integration of both trade and environment policies in a coherent manner (trade related environment measures and environment related trade measures) in order to realize gains from trade while protecting the environment.

Naughton (2010) took five specific globalization variables to examine the impact on sulfur dioxide and nitrogen oxide emission. The five variables are Trade, FDI, Neighboring countries wealth, Cross-Border pollution and Participation in international environmental treaties. The author applied spatial autoregressive regression model using 2SLS. For the appropriate study author used emission data rather than air quality data. The study found that out of the five the four globalization effects were statistically significant. For both type of emissions, he found that increase in trade intensity reduces per capita emissions with a larger effect for $\mathrm{SO}_{2}$.
In this paper, we have assembled industry-level economic and environmental data aggregated at the all India level for the fifty-eight Manufacturing industries to carry out an analysis to determine environmental effect of trade liberalization for the entire manufacturing sector across India.

\section{RESEARCH METHODOLOGY}

\section{A. Coverage}

The study analyzes the environmental degradation emerging due to trade liberalization. For this, we have assembled aggregated industry level economic and environmental data for the manufacturing sector. With the help of time series data from 1998-2008 the trade environment nexus has been determined. According to factor endowment theory, India has a comparative advantage in labor intensive technique and relatively lax environmental regulations and monitoring compared to its main trading partners. India continually expanded its international trade in pollution intensive industries. Therefore, this study covered the composition effect of trade liberalization in India. Using the secondary database, following hypothesis are tested in the present study.

1. $\mathrm{H}_{0}$ : There is no significant contribution in production of manufacturing industries from dirty industries.

2. $\mathrm{H}_{0}$ : There is no significant difference between water pollution load and toxic pollution load with respect to the value added in manufacturing industries.

\section{B. Sample and Data}

Table 1 provides a list of variables used in the industry-level analysis, unit of analysis and their data sources. Data on industrial output, net value added, no. of workers, total stock of fixed capital, gross value added come from the ASI for fifty-eight Manufacturing Industries used in this study. Due to insufficient pollution data on Indian manufacturing industries to measure industrial pollution-load and pollution intensity we used air, water and toxic pollution measures given by the Industrial Pollution Projection System (IPPS) developed by the World Bank which is based on United States (US) industries. These measures were given under the four digit ISIC (International Standard Industrial Classification) code. Many studies use IPPS outcome and data for studies on countries where pollution data are insufficient.

To calculate the pollution load for industries in India, we first mapped the NIC categories to ISIC codes. Using purchasing power parity between India and the US, we converted IPPS pollution intensities to Indian Rupees. We deflated the value-added data from the Annual Survey of Industries and the pollution loads from IPPS to 1987-88 Indian prices using wholesale price index for the manufacturing sub group. We applied the deflated pollution load (in kilograms per thousand Indian rupees) to value- 
added (per thousand Indian rupees) to obtain the pollutionintensity for each manufacturing sub group.

\section{Estimation Models}

To test hypothesis, we measure whether domestic production has shown greater increase in dirty industries relative to clean industries from 1998 to 2008 using a simple Cobb-Douglas production function. In this function capital (K) and labor (L) are taken as a proxy for capital and labor productivity. Pollution-intensity is also included as a proxy for pollution generated or pollution load by a particular industry. Pollution can be regarded as either a cost or an input to the production process. Due to the lax nature of environmental rules and regulations in India, the abatement costs associated with pollution in India are low in comparison to those of developed countries. It is therefore more logical to take pollution as an input in the production process, a method used by Jha and Rabindran (2004).

The Cobb Douglas Production Functions used is of the following form

$$
\mathrm{Y}=\mathrm{f}(\mathrm{K}, \mathrm{L}, \mathrm{P})
$$

Where $\mathrm{Y}$ is output, $\mathrm{K}$ is capital stock, $\mathrm{L}$ is labor, and $\mathrm{P}$ is amount of pollution released during the production process. The costs associated with this production function are, $r$ which is the cost of capital, w which is the wage rate and $c$ which is the cost of pollution. Capital, labor and pollution produced are inputs to the production process. Pollution is regarded as an input as mentioned previously; c/r and c/w would be lower for developing countries than corresponding ratios for developed countries under no trade.

TABLE 1 VARIABLE LABel, Unit AND SOURCE

\begin{tabular}{|l|c|c|}
\hline \multicolumn{1}{|c|}{ Variable } & Unit & Source \\
\hline Total output/Gross value added & In Lakh Rs. & $\begin{array}{c}\text { Annual Survey of Industries (ASI), Central } \\
\text { Statistical Organization (CSO) }\end{array}$ \\
\hline $\begin{array}{l}\text { Man-days per worker / net value added (labor } \\
\text { productivity) }\end{array}$ & $\begin{array}{c}\text { Net turnover per } \\
\text { worker }\end{array}$ & ASI, CSO \\
\hline $\begin{array}{l}\text { Fixed capital stock / net value added (capital } \\
\text { productivity) }\end{array}$ & $\begin{array}{c}\text { Net turnover per unit } \\
\text { of fixed } \\
\text { Capital }\end{array}$ & ASI, CSO \\
\hline $\begin{array}{l}\text { Estimated pollution load for air pollutants with } \\
\text { respect to Value Added }\end{array}$ & in millions kg. & IPPS data. \\
\hline $\begin{array}{l}\text { Estimated pollution load for air pollutants with } \\
\text { respect to Value Added }\end{array}$ & in millions kg. & IPPS data. \\
\hline $\begin{array}{l}\text { Estimated pollution load for air pollutants with } \\
\text { respect to Value Added }\end{array}$ & in millions kg. & APPS data. \\
\hline Total stock of fixed capital & In Lakh Rs. & ASI, CSO \\
\hline Net Value Added & In Lakh Rs. & ASI, CSO \\
\hline Total Output & In Lakh Rs. & ASI, CSO \\
\hline Input & In Lakh Rs. & ASI, CSO \\
\hline Gross Value Added & In Lakh Rs. & ASI, CSO \\
\hline Workers & In Lakh Rs. & . \\
\hline
\end{tabular}

With trade liberalization, developing countries would specialize in pollution intensive industries and export pollution intensive goods, turning into pollution havens. We use 3-digit NIC level data for manufacturing industries to estimate pollution load. The regression model is:

$\ln \left(\mathrm{Y}_{\mathrm{it}}\right)=\alpha+\beta_{1} \ln \left(\mathrm{K}_{\mathrm{it}}\right)+\beta_{2} \ln \left(\mathrm{L}_{\mathrm{it}}\right)+\beta_{3} \ln \left(\mathrm{Pa}_{\mathrm{it}}\right)+\beta_{4} \ln \left(\mathrm{Pw}_{\mathrm{it}}\right)+$ $\beta_{5} \ln \left(\mathrm{Pt}_{\mathrm{it}}\right)+\mu$

where, $\mathrm{Y}$ is the total output as a fraction of gross value added in per manufacturing industry $\mathrm{i}$ for time period $\mathrm{t}$ measured at the 3-digit NIC level (there are total 58, 3-digit NIC manufacturing industries); $\mathrm{K}$ is industry-wise capital productivity; L is industry-wise labor productivity (here we use worker productivity as a proxy); $\mathrm{Pa}, \mathrm{Pw}$ and $\mathrm{Pt}$ is industry-wise total estimated pollution-load respectively for air, water and toxic pollutants with respect to the value added. The coefficients $\beta_{3}, \beta_{4}$ and $\beta_{5}$ capture the significant contribution in production of manufacturing industries from dirty industries. If domestic production does not show significant contribution in production of manufacturing industries from dirty industries then we would have, $\beta_{3}=0$, $\beta_{4}=0$ and $\beta_{5}=0$. The results for equation are presented in Table 5.

\section{LIMITATIONS OF THE STUDY}

There are several limitations with this study. First, The IPPS is based upon the 4-digit industrial classification at SIC level for the year 1987 while the NIC and ASI has revised its classification up to the year 2008. In order to determine the pollution intensity coefficient of various manufacturing industries, the study has to depend on the 1987 classification. Therefore the IPPS classification is not able to capture the effects of the modernization of techniques 
that emits less pollution. Second, absence of Indian pollution-intensity data, we have used pollution measures from the US as proxies (as suggested by previous IPPS studies). Third, Due to lack of plant-level emission data it is not possible to actually test whether emissions increased or decreased in manufacturing industries. Lastly, unorganized manufacturing sector has not been included in to the study due to non-availability of data; this may not reflect the exact picture of environmental degradation due to trade liberalization, however, even then the importance of the study cannot be ignored. Now we establish the nexus between industrial output and total estimated pollution load by various sources (Air, Water and Toxic).

TABLE 2 MANI AND WHEELER's CLASSIFICATION OF INDUSTRIES

\begin{tabular}{|c|c|c|c|c|}
\hline Rank & Air & Water & Toxic/Metal & Overall \\
\hline 1 & Iron and Steel & Iron and Steel & Non-Fer Metals & Iron and Steel \\
\hline 2 & Non-Fer Metals & Non-Fer Metals & Iron and Steel & Non-Fer Metals \\
\hline 3 & Non-fer minerals & Pulp and paper & $\begin{array}{c}\text { Industrial } \\
\text { Chemicals }\end{array}$ & $\begin{array}{c}\text { Industrial } \\
\text { Chemicals }\end{array}$ \\
\hline 4 & Petro Coal Prod & Mis Minerals & Leather Products & Petro Refineries \\
\hline 5 & Pulp and paper & $\begin{array}{c}\text { Industrial } \\
\text { Chemicals }\end{array}$ & Pottery & Non-fer minerals \\
\hline 6 & Petro Refineries & Other Chemicals & Metal Products & Pulp and paper \\
\hline 7 & $\begin{array}{c}\text { Industrial } \\
\text { Chemicals }\end{array}$ & Beverages & Rubber Products & Other Chemicals \\
\hline 8 & Other Chemicals & Food Products & Electrical products & Rubber Products \\
\hline 9 & Wood Products & Rubber Products & Machinery & Leather Products \\
\hline 10 & Glass products & Petro Products & Non-Met Minerals & Metal Products \\
\hline
\end{tabular}

Source: Mani and Wheeler (1998)

Manufacturing industries can be classified into "clean" and "dirty" industries and their trends observed over a period of time. In 1999 Central Pollution Control Board (CPCB) identified 17 "highly polluting" industries for the implementation of pollution control program. These sectors have also massive share of output and employment. They are: (1) aluminum smelting; (2) basic drugs and pharmaceuticals; (3) caustic soda; (4) cement; (5) copper smelting; (6) distillery; (7) dyes and dye intermediates; (8) fertilizer; (9) integrated iron and steel; (10) leather; (11) oil refineries; (12) pesticide (13) petrochemical; (14) paper and pulp; (15) sugar; (16) thermal power plants, and (17) zinc smelting.

TABLE 3 Industrial OUtPut GROWTH By Two-Digit INDUSTRY GROUPS, 1991-2008

(AVERAGE OF ANNUAL PERCENTAGE GROWTH RATES)

\begin{tabular}{|l|l|c|c|}
\hline \multicolumn{1}{|c|}{ NIC -1998} & \multicolumn{1}{c|}{ Industry Description } & \multicolumn{2}{c|}{ Growth Rate 1981- 1991 1992-2008 } \\
\hline $151-154$ & Food Products & 6.6 & 5.2 \\
\hline $155+16$ & Beverages and Tobacco & 4.4 & 8 \\
\hline $171-173+181+014+505$ & Textiles & 4.6 & 5.2 \\
\hline $182+19$ & Leather and Fur & 3.4 & 4.4 \\
\hline $20+361$ & Wood & -2.7 & -1.5 \\
\hline $21+22$ & Paper and Printing & 9.1 & 3.9 \\
\hline $23+25$ & Rubber and Petroleum & 13.6 & 5.8 \\
\hline 24 & Chemicals & 9.3 & 8.3 \\
\hline 26 & Non Metallic Mineral Products & 8.7 & 7.3 \\
\hline $271+272+2731+2732$ & Basic Metals & 5.8 & 7.9 \\
\hline $28+29+30$ & Metal Products and Machinery & 6 & 12.7 \\
\hline $31+32$ & Electrical Machinery & 10.6 & \\
\hline $33+369$ & Other Manufacturing & & \\
\hline $34+35$ & Transport Equipment & 5.5 & 8.5 \\
\hline & GDP Manufacturing & 6.3 & 8.6 \\
\hline
\end{tabular}


There is one more categorization to distinguish dirty and clean industries (Mani and Wheeler classification, 1998). It is based on categorizing the industries on the basis of their emissions intensity (emissions per $\$$ of output) and computing average sectoral rankings for conventional air pollutants, water pollutants and toxic pollutants. Mani and Wheeler classification (as shown in Table 2) is similar to the CPCB classification. So, we here using CPCB classification for examining the degree to which the composition of India's manufacturing value added has shifted towards clean or dirty sectors. After the liberalization, manufacturing output increased by about average $15.23 \%$ (Total 250\%) during 1998-2008. There is dramatic shift in the composition of manufacturing towards cleaner to dirty sectors. This indicates that the production became more pollution intensive.

Due to impact of liberalization, dirty and clean manufacturing industry pollution load for Air Pollutants $\left(\mathrm{SO}_{2}, \quad \mathrm{NO}_{2}, \mathrm{CO}\right.$, Volatile Organic Compounds, Fine Particulates, Total Suspended Particulates) with respect to value added (in million kg.) increasing respectively, by average $16.18 \%$ (Total 268\%) and $7.29 \%$ (Total $79.92 \%$ ). There is rapid shift in dirty manufacturing industry pollution load after 2001-02. We find that due to impact of liberalization, dirty and clean manufacturing industry pollution load for Water Pollutants (Biological Oxygen
Demand (BOD), Total Suspended Solids (TSS)) with respect to value added (in million $\mathrm{kg}$.) increasing respectively, by average $17.28 \%$ (Total $229 \%$ ) and $7.56 \%$ (Total $75 \%$ ). The gap between dirty and clean industry pollution load became wider. We find that due to impact of liberalization, dirty and clean manufacturing industry pollution load for Toxic Pollutants (by medium Air, Land and Water) with respect to value added (in million $\mathrm{kg}$.) increased respectively, by average $10.35 \%$ (Total $130.37 \%$ ) and $6.14 \%$ (Total $65 \%$ ).

Comparatively, percentage change in toxic pollution load was lesser than air and water pollutants. After the analysis, we find that industrial pollution load performances with respect to the value added in dirty versus clean industry. While the cleaner sectors have remained relatively clean; however, within the dirty sectors, the toxic polluting ones have become relatively dirtier while water polluting ones have become relatively cleaner. To capture the real picture of air and water pollution load in dirty and clean industry, by excluding toxic pollution load we see that comparatively air pollution load rapidly increase than water pollution load. Table 5 presents the regression results for the changes in the composition of manufacturing output. The dependent variable in logged of the ratio of total output and gross value added.

TABLE 4 COMPARING INDUSTRIAL GROWTH, 1981-91 AND 1992-2008

\begin{tabular}{|c|c|c|c|c|c|}
\hline NIC & Industry Groups & 1992-96 & 1997-2002 & 2003-08 & 1992-08 \\
\hline $20-21$ & Food & 4.6 & 2.7 & 4.5 & 3.9 \\
\hline 22 & Beverage & 9.2 & 11.6 & 14.3 & 11.9 \\
\hline 23 & Cotton Textiles & 6.8 & 2.4 & 4.9 & 4.6 \\
\hline 24 & Silk \& Wool Textiles & 10.7 & 9.0 & 4.3 & 7.8 \\
\hline 25 & Jute & 1.3 & -0.2 & 4.3 & 1.8 \\
\hline 26 & Textile Products & 0.6 & 3.8 & 10.3 & 5.2 \\
\hline 27 & Wood & 5.0 & -4.3 & 7.2 & 2.5 \\
\hline 28 & Paper & 7.4 & 5.4 & 7.3 & 6.6 \\
\hline 29 & Leather & 1.2 & 8.3 & 1.2 & 3.7 \\
\hline 30 & Rubber & 3.4 & 6.7 & 6.4 & 5.6 \\
\hline 31 & Chemicals & 6.6 & 8.0 & 9.2 & 8.0 \\
\hline 32 & Nonmetallic Minerals & 8.9 & 9.0 & 6.6 & 8.1 \\
\hline 33 & Basic Metals & 13.6 & 3.0 & 12.4 & 9.4 \\
\hline 34 & Metal Products & -2.2 & 6.4 & 3.4 & 2.8 \\
\hline $35-36$ & Electrical \& Non Electrical Machinery & 3.0 & 6.4 & 12.1 & 7.4 \\
\hline 37 & Transport Equipment & 8.0 & 7.6 & 11.0 & 8.9 \\
\hline 38 & Other Manufacturing & 3.5 & 4.8 & 13.2 & 7.4 \\
\hline $2-3$ & Manufacturing & 6.1 & 5.6 & 8.9 & 6.9 \\
\hline
\end{tabular}

Sources: based on data collected from various issues of Economic Survey

Polled ordinary least square estimates and the Log - Log or Constant Elasticity model have been used. Regression results show that manufacturing value added from more water pollution intensive sectors increased at a higher rate than toxic pollution intensive sector as the size of the coefficient on toxic pollution load is smaller than water pollution load. We find robust evidence that water pollution 
load with respect to the value added increased at a greater $\quad$ rate (217\%) relative to toxic pollution load (117\%).

TABLE 5 POLLED REGRESSION OUTPUT

\begin{tabular}{|c|c|c|}
\hline Dependent variable: output/value added & Output & Output(without including Air pollution load)\# \\
\hline Constant & $\begin{array}{l}1.954068 \\
(0.075536)\end{array}$ & $\begin{array}{c}1.990822 \\
(0.083592) \\
\end{array}$ \\
\hline Capital productivity & $\begin{array}{l}0.104071 * \\
(0.027043)\end{array}$ & $\begin{array}{l}0.101666^{*} \\
(0.030116) \\
\end{array}$ \\
\hline Labor productivity & $\begin{array}{l}-0.106589^{*} \\
(0.021947) \\
\end{array}$ & $\begin{array}{l}-0.103683^{*} \\
(0.024542)\end{array}$ \\
\hline Air pollution load & $\begin{array}{l}-0.011920 \\
(0.010128)\end{array}$ & \\
\hline Water pollution load & $\begin{array}{l}0.027867^{*} \\
(0.005196)\end{array}$ & $\begin{array}{l}0.026450^{*} \\
(0.004529)\end{array}$ \\
\hline Toxic pollution load & $\begin{array}{l}-0.029099^{*} \\
(0.014671)\end{array}$ & $\begin{array}{l}-0.039712^{*} \\
(0.010172)\end{array}$ \\
\hline Observations & 550 & 550 \\
\hline R-squared & 0.146091 & 0.143917 \\
\hline Adjusted R-squared & 0.138242 & 0.137633 \\
\hline
\end{tabular}

TABLE 6 DESCRIPTIVE STATISTICS

\begin{tabular}{|l|c|c|}
\hline \multicolumn{1}{|c|}{ Variable } & Mean & Standard Deviation \\
\hline Total output/Gross value added & 5.40 & 2.74 \\
\hline Capital productivity & 2.16 & 1.70 \\
\hline Labor productivity & 5.92 & 224.0259 \\
\hline Air pollution load & 62.69769 & 258.9367 \\
\hline Water pollution load & 37.82915 & 7063.928 \\
\hline Toxic pollution load & 2042.227 & \\
\hline
\end{tabular}

Regression results show that water pollution intensive output showed a positive and significant increase during this period. The study finds that an increase of one percent point in water pollution loads leads to a 0.02 percent increase in output. Toxic pollution intensive output showed a negative but significant increase, we find that an increase of one percent point in toxic pollution loads leads to a 0.03 percent decline in output. Capital productivity showed a positive and significant increase. An increase of one percent point in capital productivity leads to a 0.10 percent increase in output. Labor productivity showed a negative but significant increase. An increase of one percent point in labor productivity leads to a 0.10 percent decline in output. $\mathrm{P}$ value of 'F statistics' is significant which proves our model is significant. $\mathrm{R}^{2}$ is 0.146 implies that about $15 \%$ variation in dependent variable explained by explanatory variable.

\section{CONCLUSIONS}

Present study makes an attempt to analyze the impact of trade liberalization on the environment in the Indian context during 1998-2008. It can be concluded that there has been a change in composition of output in India that parallels the gradual improving and opening up of the economy. Manufacturing output has been significantly higher from the water pollution intensive sectors compared to the air and toxic pollution intensive sectors. This evidence provides some support for concerns raised about, that there is significant contribution in production of manufacturing industries from dirty industries as compare to the clean industries. On the one side the trade liberalization enhances the competiveness and brings advanced technology to developing countries, however, on the other hand, it generates adverse impact on the environment via increasing emissions and depletion of resources. The study shows that due to trade liberalization exports have increased in the more polluting industries relative to the less pollution intensive ones. Although, trade liberalization is raising the level of economic growth in India but it has led deterioration in environmental quality by increasing emissions of pollutants. That is why; there is a trade-off between the economic growth and environmental quality as suggested by Environmental Kuznet Curve.

Trade liberalization in developing countries may result in shifts in the composition of production and exports more pollution-intensive manufacturing industries. The results from this study show that there has been an increase in air and water pollution intensive manufacturing industries after trade liberalization. Overall, these results provide some evidence in support of the concerns about the negative environmental consequences of India's trade liberalization and call for public policy responses. 


\section{REFERENCES}

[1] Antweiler, Werner, Copeland, Brian R., \& M. Scott Taylor. 2001. "Is Free Trade Good for the Environment?" NBER, Working Paper No. 6707.

[2] Azhar, Usman, Samina Khalil \& MohsinHasnain Ahmed (2006). Environmental Effects of Trade Liberalization: A Case Study of Pakistan, Balochistan University of Information Technology and Management Sciences, Quetta

[3] Beghin, J. \& Potier, M., (1997). Effects of Trade Liberalization on the Environment in the Manufacturing Sector, World Econ. 20(4).

[4] Dasgupta, Susmita, Benoit Laplante, Hua Wang \& David Wheeler (2002). Confronting the Environmental Kuznets Curve", Journal of Economic Perspectives, 16(1).

[5] Dessus, S. \& Bussolo, M., (1998). Is there a trade-off between trade liberalization and pollution abatement? A computable general equilibrium assessment applied to Costa Rica. Journal of Policy Modeling, 20(1).

[6] Dinda, S. (2006). Globalization and environment: Can pollution haven hypothesis alone explain the impact of globalization on environment? MPRA Paper, 50590.

[7] Grossman, G. \& Krueger, A.B. (1993). Environmental Impacts of a North American Free Trade Agreement. Centre for Economic Research, Discussion Paper 644.

[8] Gupta, Shreekant. (2000). Estimating Benefits and Cost Savings through Market Based Instruments: An Application Using State-Level Data from India. Working Paper.
[9] Hettige, Hemamala, Paul Martin, Manjula Singh, \& David Wheeler. The Industrial Pollution Projection System. Policy Research Working Paper \#1431, The WorldBank.

[10] Jena, P.R., N. C. Sahu \& Rath. B. (2005). Does Trade Liberalisation Create Pollution Haven? An Indian Experience, paper presented at the "International Conferenceon Environment and Development: Developing Countries Perspective. April 7-8, 2005, ITD, SIS, Jawaharlal Nehru University, New Delhi.

[11] Jha, Shreyasi \& Rabindran S.G. (2004). Environmental Impact of India's Trade Liberalization. paper presented at the "75 years of Development Conference” held at Cornell University, New York, 7-9 May

[12] Kukla, Anna \& Gryz. (2008). Economic growth, international trade and air pollution: A decomposition analysis. Journal of Ecological Economics, 68.

[13] Low \& Yates (1992). Do Dirty Industries Migrate, International Trade and Development, World Bank Discussion Paper No. 159.

[14] Mani, Muthukumara, \& David Wheeler (2010). In search of pollution havens?Dirty Industry in the World Economy, 1960-1999." Journal of Environment and Development, 7(3), 215-247.

[15] Mukhopadhyay, K. and D. Chakraborty (2005). Is liberalization of trade good for the environment? Evidence from India, Asia-Pacific Development Journal. 12(1), 109-136

[16] Mukhopadhyay, Kalkali (2006), "Impact on the Environment of Thailand's Trade with OECD Countries" Asia-Pacific Trade and Investment Review, 2(1).

[17] Naughton, T, Helen. (2010). Globalization and Emissions in Europe. The European Journal of Comparative Economics, 7(2), 503-519. 